\title{
Kinetics of desensitization and recovery from desensitization for human a4 32 -nicotinic acetylcholine receptors stably expressed in SH-EP1 cells
}

\author{
Kewei D YU ${ }^{1}$, Qiang LIU $^{1}$, Jie WU ${ }^{1, *}$, Ronald J LUKAS ${ }^{2, *}$ \\ ${ }^{1}$ Division of Neurology and ${ }^{2}$ Division of Neurobiology, Barrow Neurological Institute, Phoenix, AZ 85013, USA
}

\begin{abstract}
Aim: Studies were conducted to define the kinetics of the onset of and recovery from desensitization for human a4 $\beta 2$ nicotinic acetylcholine receptors (nAChR) heterologously expressed in the SH-EP1 human epithelial cell line.

Methods: Whole-cell patch clamp recordings were performed to evaluate a4 32 -nAChR currents.

Results: Application of $0.1 \mu \mathrm{mol} / \mathrm{L}$ nicotine or $1 \mathrm{mmol} / \mathrm{L}$ acetylcholine $(\mathrm{ACh})$ for $1 \mathrm{~s}$ or longer induced two phases, with time constants of $\sim 70$ and $\sim 700 \mathrm{~ms}$, for the onset of a $4 \beta 2-n A C h R$ desensitization. For a given duration of agonist exposure, recovery from desensitization induced by nicotine was slower than recovery from ACh-induced desensitization. Comparisons with published reports indicate that time constants for the recovery of a $4 \beta 2$-nAChRs from desensitization are smaller than those for the recovery of human muscle-type $\mathrm{nAChRs}{ }^{[1]}$ from desensitization produced by the same concentrations and durations of exposure to an agonist. Moreover, the extent of human a $4 \beta 2-n A C h R$ desensitization and rate of recovery are the same, regardless of whether they are measured using whole-cell recording or based on published findings ${ }^{[2]}$ using isotopic ion flux assays; this equality demonstrates the equivalent legitimacy of these techniques in the evaluation of nAChR desensitization. Perhaps most significantly, recovery from desensitization also was best fit to a biphasic process. Regardless of whether it was fit to single or double exponentials, however, half-times for recovery from desensitization grew progressively longer with an increased duration of agonist exposure during the desensitizing pulse.

Conclusion: These findings indicate the existence of a $4 \beta 2-n A C h R s$ in many distinctive states of desensitization, as well as the induction of progressively deeper states of desensitization with the increased duration of agonist exposure.
\end{abstract}

Keywords: acetylcholine; nicotinic acetylcholine receptors; patch-clamp techniques; SH-EP1 cells

Acta Pharmacologica Sinica (2009) 30: 805-817; doi: 10.1038/aps.2009.48

\section{Introduction}

Nicotinic acetylcholine receptors ( $\mathrm{nAChRs)}$ are expressed as diverse subtypes composed of distinctive combinations of subunits and play a variety of important physiological roles ${ }^{[3]}$. a4 $32-\mathrm{nAChRs}$ have received much attention because they seem to be the predominant $n A C h R$ subtype in the brain and the major, high-affinity nicotine binding sites also implicated in nicotine dependence ${ }^{[4,5]}$. Up-regulation of brain radioligand binding sites corresponding to $\alpha 4 \beta 2$ nAChRs after chronic nicotine exposure has been observed both in human smokers and in rats ${ }^{[4,6-8]}$, whereas a substantial decrease in brain $\alpha 4 \beta 2$-nAChR-like radioligand binding

* Correspondence to Dr Ronald J LUKAS or Prof Jie WU.

E-mail rlukas@chw.edu or Jie.Wu@chw.edu

Received 2009-02-16 Accepted 2009-03-17 sites occurs in neurodegenerative disorders such as Alzheimer's and Parkinson's diseases ${ }^{[9-11]}$. $\alpha 4 \beta 2-n A C h R s$ also have been implicated in certain types of epilepsy ${ }^{[12]}$, Tourette's syndrome ${ }^{[13]}$, and neural development ${ }^{[14]}$, reinforcing their potentially critical roles in physiological and pathological processes in the central neural system.

Regardless of whether they mediate classic excitatory neurotransmission when expressed on somatodendritic sites postsynaptic to cholinergic input or modulate release of neurotransmitters when expressed on nerve terminals ${ }^{[15]}$, questions remain regarding the roles of $\mathrm{nAChR}$ activation and inactivation in their physiological functions. It has long been known that agonist binding to nAChRs induces transient channel gating, rapidly followed by a process called "desensitization" that is associated with channel closure ${ }^{[16]}$. However, our understanding of desensitization remains incomplete. 
Current models of nAChR desensitization, like most ligandgated ion channels, are based on cyclical schemes with two distinct desensitized states: the early, quickly desensitized state and a more slowly inactivating state ${ }^{[17-19]}$. However, our previous studies of the kinetics of the recovery of muscletype $\mathrm{nAChR}$ function from sustained nicotine exposure suggested the existence of more than two desensitized states, a hypothesis based in part on the observation that the halftimes for the recovery from functional inactivation grew longer as the duration of desensitizing agonist application increased ${ }^{[1]}$.

To determine whether observations about desensitization made using muscle-type nAChRs are generalizable to other $\mathrm{nAChR}$ subtypes, we undertook studies of the kinetics of desensitization and recovery from desensitization using human SH-EP1 epithelial cells transfected with human $\mathrm{nAChR} \alpha 4$ and $\beta 2$ subunits to stably and heterologously express the human $\alpha 4 \beta 2-\mathrm{nAChR}{ }^{[20]}$. We reasoned that such studies, especially given complications due to residual nicotine in investigations of $\mathrm{nAChR}$ heterologously expressed in much larger Xenopus oocytes, might provide a better assessment of the kinetics of $\alpha 4 \beta 2$-nAChR desensitization and recovery from desensitization that would be more appropriate for an improved understanding of those processes in neurons of a similar size.

\section{Materials and methods}

Expression of human $\alpha 4 \beta 2-n A C h R$ in transfected SH-EP1 cells The SH-EP1-ha4 $\beta 2$ cell line heterologously expressing human $\alpha 4 \beta 2-\mathrm{nAChR}$ was created, characterized and maintained as described earlier ${ }^{[20]}$. Cells seeded initially at $\sim 20 \%$ confluence onto 35 -mm dishes were used for electrical recording. The efficiency of obtaining tight patch-clamp recording seals and functional $\alpha 4 \beta 2$-nAChR expression appeared to be optimal three to four days later.

Patch-clamp whole-cell current recordings Conventional whole-cell current patch clamp recording at a holding potential $\left(V_{\mathrm{H}}\right)$ of $-60 \mathrm{mV}$ coupled with fast drug application and removal using a perfusion system (SF-77B, Warner Instruments) was applied in this study ${ }^{[21]}$. The internal patch pipette solution included $140 \mathrm{mmol} / \mathrm{L} \mathrm{KCl}, 4$ $\mathrm{mmol} / \mathrm{L} \mathrm{MgSO}_{4}, 0.1 \mathrm{mmol} / \mathrm{L}$ EGTA, $10 \mathrm{mmol} / \mathrm{L}$ HEPES, and $3 \mathrm{mmol} / \mathrm{L}$ ATP ( $\mathrm{pH}$ adjusted to 7.2 with $\mathrm{KOH}$ ). The pipette resistance filled with internal solution was 3-5 $\mathrm{M} \Omega$. The standard external solution included $120 \mathrm{mmol} / \mathrm{L} \mathrm{NaCl}$, $3 \mathrm{mmol} / \mathrm{L} \mathrm{KCl}, 2 \mathrm{mmol} / \mathrm{L} \mathrm{MgCl} 2,2 \mathrm{mmol} / \mathrm{L} \mathrm{CaCl}_{2}, 25$ $\mathrm{mmol} / \mathrm{L} \mathrm{D}$-glucose, and $10 \mathrm{mmol} / \mathrm{L}$ HEPES ( $\mathrm{pH}$ adjusted to 7.4 with Tris-base). In experiments involving acetylcho- line $(\mathrm{ACh})$ exposure, $1 \mu \mathrm{mol} / \mathrm{L}$ atropine sulfate was added to the standard solution to exclude any possible influences of muscarinic receptors.

Briefly, cells plated on poly-lysine-coated $35-\mathrm{mm}$ culture dishes were placed on the stage of an inverted microscope (Olympus iX7, Lake Success, NY) and continuously superfused with standard external solution. Glass microelectrodes were used to form tight seals (>1G $\Omega$ ) on the cell surface until suction was applied for conversion to conventional whole-cell recording. Cells were then voltage-clamped at a holding potential $\left(V_{\mathrm{H}}\right)$ of $-60 \mathrm{mV}$, and ion currents in response to the application of ligands were measured (Muticlamp 700A amplifier, Axon Instrument, Foster City, CA, USA). Data were filtered at $2 \mathrm{kHz}$, acquired at $6 \mathrm{kHz}$, displayed and digitized on-line (Axon Instruments Digidata 1322A series A/D board), and stored on a hard drive. Offline data acquisition and analyses were performed using Pclamp8 (Axon Instruments), and results were plotted using Origin 5.0 (Microcal, North Hampton, MA).

To initiate whole-cell current responses, agonists were rapidly delivered to the cell using the SF-77B system. The time needed to fully change from standard extracellular solution to drug perfusion and back again was less than 20 ms. Drugs used in the present study were nicotine and $\mathrm{ACh}$ (Sigma Chemical Co, St Louis, MO). In the early stages of this study, most recording was done using cells attached to the culture dish; in later stages, however, the "lifted cell" technique was applied. Briefly, after gigaseal formation, a $0.125 \%$ trypsin solution made in extracellular medium was applied via superfusion for 10-20 s and removed by $30 \mathrm{~s}$ of superfusion with extracellular Ringer's solution. Superfusion was stopped, and the micromanipulator was moved to determine whether the cell would then lift off the dish while maintaining gigaseal contact with the recording pipette. In 30\%-50\% of the cases where lifted cell recording then was achieved, superfusion was reinitiated. In the vast majority of cases, the quality of the recording and the stability of the gigaseal were improved (facilitating longer-term study of a cell) after the lifted cell state was achieved. Indications are provided in the narrative and/or figure legends about the cell state during recording.

For analysis of the rate of onset of desensitization, wholecell current data were fit over the period from the point just after the peak inward current was obtained to the end of the drug application period (ie, at the end of the 4 s period of drug exposure). Generally, data were obtained using a fully efficacious concentration of agonist, and the desensitization from the peak to steady state inward current response was fit to a bi-exponential expression (Clampfit 8, Axon Instru- 
ments):

$$
f(t)=A_{f}^{-t / \tau f}+A_{s}^{-t / \tau s}+C
$$

where $f(t)$ is the whole-cell current amplitude at any given time, $A_{f}$ is the magnitude of the more quickly decaying desensitization process characterized by time constant $\tau f, A_{s}$ is the magnitude of the more slowly decaying desensitization process characterized by time constant $\tau s$, and $\mathrm{C}$ is the steady state current that does not fully desensitize.

For analysis of the kinetics of recovery from desensitization, peak current responses to "test" pulses of agonist were sampled at specific times after the peak current responses to an initial, "desensitizing" pulse of drug application. The amplitudes of the test pulse responses were normalized to the amplitude of the desensitizing pulse response and plotted against the interval between desensitizing and test pulses. Data were fit to both the single- $\left(Y_{2}=0\right)$ and the double-phase exponential expression:

$$
\mathrm{Y}=\mathrm{Y}_{0}+\mathrm{Y}_{1}\left(1-\exp (-0.693 \mathrm{X} / \tau \mathrm{f})+\mathrm{Y}_{2}(1-\exp (-0.693 \mathrm{X} / \tau \mathrm{s})\right.
$$

(Prism V3.0, GraphPad, San Diego, CA) for the observed peak current amplitude $\mathrm{Y}$, the baseline current amplitude (reflecting incomplete desensitization of responses upon shorter-term agonist exposure) $\mathrm{Y}_{0}$, and magnitudes of the quickly and slowly recovering processes $Y_{1}$ and $Y_{2}$ that are characterized by time constants $\tau$ f and $\tau s$, respectively. Parameters fit to bi-exponential processes are reported in some cases to fit the data to maintain uniformity of data analysis, because some of the results were clearly and significantly $(P<0.05)$ better fit by a bi-exponential expression than a mono-exponential equation based on a chi-square analysis of the results. Parameters fit with mono-exponential equations are reported in some cases to facilitate comparisons with other findings reported in the literature and fit as singlephase processes. For studies of the recovery from desensitization, $\mathrm{Y}_{0}$ was not always set to zero because shorter agonist pretreatment times did not produce the full desensitization observed for longer desensitizing agonist exposures. Thus, for short-term exposure protocols, $Y_{0}$ was set as the inward current amplitude at the end of the desensitizing pulse. This was chosen in part because experimental studies (not shown here) confirmed that the amplitude of the test pulse peak current response was indeed the same as the amplitude of the steady state whole cell current response at the end of the desensitizing pulse if the interpulse interval was very short (eg, 0.1-0.2 s). For longer-term exposures (eg, $180 \mathrm{~s}$ ), $\mathrm{Y}_{0}$ was set to zero because the steady state response to the desensitizing pulse fully desensitized to the baseline. Additionally, because the non-zero $\mathrm{Y}_{0}$ differed for a specific condition of agonist exposure for responses recorded from lifted or attached ("unlifted") cells for short-term agonist exposures, data were segregated and fit to the different inward current amplitude values for lifted and unlifted cells at the end of the desensitizing pulse. The rate constants for the recovery from desensitization were indistinguishable both across the two cell conditions and from those obtained when raw data from lifted and unlifted cells were combined and analyzed as a single data set, as has been done for the recovery from desensitization studies presented below.

All data points are expressed as means \pm SEM. Statistical comparisons utilized Student's $t$-test, and a $P<0.05$ was considered significant. All experiments were performed at room temperature $\left(22 \pm 1{ }^{\circ} \mathrm{C}\right)$.

\section{Results}

Studies of whole-cell current responses to ACh applied at different doses for $4 \mathrm{~s}$ to SH-EP1 cells heterologously expressing the human $\alpha 4 \beta 2$-nAChR were initiated (Figure $1)$. The typical temporal pattern of the whole-cell response consisted of: 1) a quick rise from the initiation of agonist exposure to a peak inward current and 2) a decay (through a process that we operationally define as acute desensitization) of inward current to a much lower amplitude, but still nonzero, steady state level. Upon drug removal, $\alpha 4 \beta 2$-nAChRmediated inward currents quickly returned to baseline levels. ACh dose-dependence for whole-cell current profiles is evident in that peak currents achieve their highest levels at the higher agonist doses. Further, the initial phase of acute desensitization is faster for exposure to higher agonist doses.

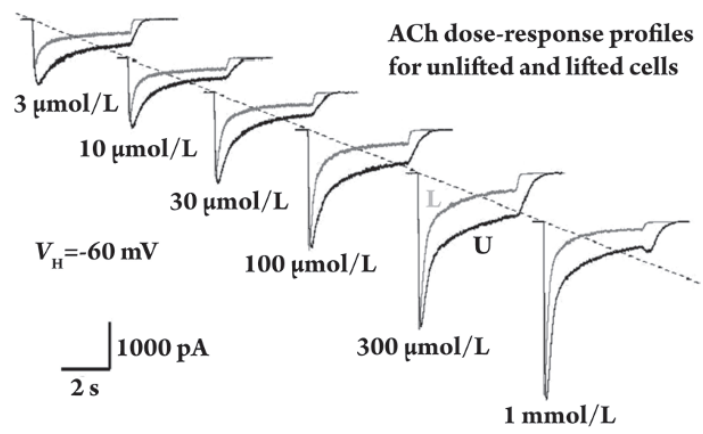

Figure 1. Typical whole-cell current responses for unlifted and lifted cells. Whole-cell current responses to $\mathrm{ACh}$ at the indicated doses were recorded at a holding potential of $-60 \mathrm{mV}$ either from SH-EP1-h $\alpha 4 \beta 2$ cells attached to the culture dish (unlifted; U) or after lifting of the same cell (lifted; L) as described under Materials and Methods. Peak current amplitudes have not been normalized and are comparable prior to and after lifting, but the kinetics of the whole-cell response is accelerated when using lifted cell recording. This acceleration is likely due to more rapid solution exchange around the lifted cell. The time and current amplitude scale bars apply to all traces. 
The traces illustrated are from studies comparing the properties of whole-cell current recordings from attached, unlifted cells as well as the same cells in the lifted format. These studies indicate that there is no significant difference in the peak current response amplitude upon acute agonist challenge with $1 \mathrm{mmol} / \mathrm{L}$ ACh $(-52.4 \pm 4.9 \mathrm{pA} / \mathrm{pF}$ for unlifted, $n=23$; $-67.2 \pm 22.6 \mathrm{pA} / \mathrm{pF}$ for lifted, $n=8 ; P=0.542)$ or $100 \mu \mathrm{mol} / \mathrm{L}$ nicotine $(-50.3 \pm 7.2 \mathrm{pA} / \mathrm{pF}$ for unlifted, $n=16 ;-76.3 \pm 14.2$ $\mathrm{pA} / \mathrm{pF}$ for lifted, $n=10 ; P=0.125)$, suggesting that brief trypsinization to allow conversion to the lifted cell condition did not adversely affect human $\alpha 4 \beta 2$-nAChR function. These studies did reveal, however, that the kinetics for the responses (ie, the rate of achievement of the peak current response, the time needed to achieve a peak response, and the rate of acute desensitization from the peak to steady state current levels at the end of the agonist challenge) were accelerated during recordings from lifted cells. Even the rate of return to baseline levels for inward current after drug removal was faster for lifted than unlifted cells. These findings suggest that the rate and extent of drug and solution change around the cell was much faster and uniform in the lifted cell configuration. Additionally, they imply that the topography of attached cells in relation to the drug delivery device influenced the apparent kinetics of whole-cell current responses. Moreover, the extent of acute desensitization for a given cell exposed to a specific dose of agonist for a specific period of time was larger for lifted cells than it was for the same cells challenged while attached to the culture plate, perhaps indicating better synchrony in the activation and desensitization of cellular $\alpha 4 \beta 2$-nAChRs in the lifted format. Nevertheless, as we show below, rates of recovery from acute desensitization, which were much slower than rates for channel opening and the onset of acute desensitization, were indistinguishable regardless of whether they were obtained using lifted or unlifted cells. Consequently, studies of the kinetics of the recovery from acute desensitization (see below) combine data obtained using lifted and unlifted cells.

A series of typical whole-cell current responses of lifted SH-EP1-h $\alpha 4 \beta 2$ cells that were exposed to fully efficacious doses of ACh $(1 \mathrm{mmol} / \mathrm{L})$ or nicotine $(0.1 \mathrm{mmol} / \mathrm{L})$ for different periods of drug exposure $(0.2,0.3,0.5,1$, and $4 \mathrm{~s}$; Figure 2A, 2B) revealed that both agonists induced a quick rise to the peak whole-cell currents. Due to acute desensitization, this was followed by a quick decay of the inward current to a much lower amplitude, but still non-zero, steady state level. Upon drug removal, inward currents quickly returned to baseline levels after exposure to ACh. However, the return of the inward current to baseline levels occurred more slowly after exposure to nicotine. Comparisons of the
A

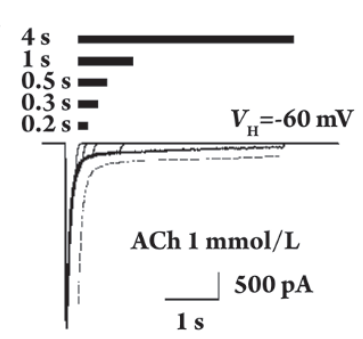

B

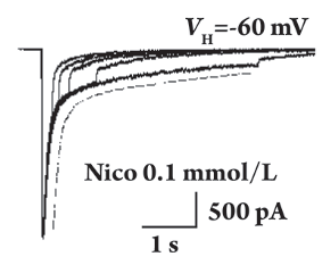

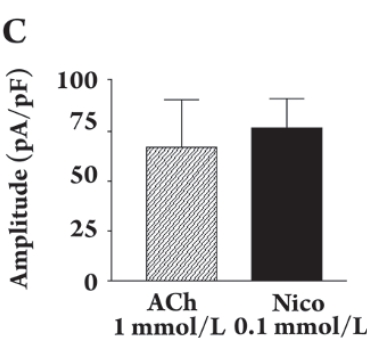

D

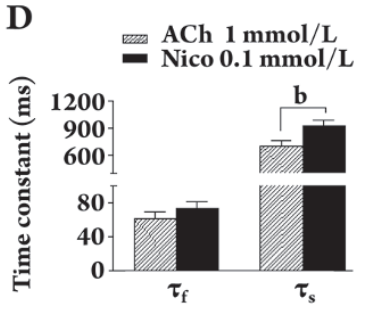

Figure 2. Desensitization of $\alpha 4 \beta 2-n A C h R$ function. Overlapped, typical whole-cell current responses of $\alpha 4 \beta 2$-nAChRs heterologously expressed in SH-EP1-h $\alpha 4 \beta 2$ cells to $1 \mathrm{mmol} / \mathrm{L} \mathrm{ACh} \mathrm{(A)} \mathrm{or} 0.1$ $\mathrm{mmol} / \mathrm{L}$ nicotine (B) applied for the indicated periods (horizontal bars above traces; $0.2,0.3,0.5,1$, and $4 \mathrm{~s}$ of exposure) are shown for records normalized to show equal peak current responses. Traces shown for $\mathrm{ACh}$ or nicotine responses are from the same cells and were recorded at a holding potential $\left(V_{\mathrm{H}}\right)$ of $-60 \mathrm{mV}$. Dashed lines in panels $\mathrm{A}$ and $\mathrm{B}$ offset from the traces show bi-exponential fits to the data, yielding rate constants for the onset of desensitization of $\tau_{\mathrm{f}}=46.7 \mathrm{~ms}$ and $\tau_{\mathrm{s}}=890.5 \mathrm{~ms}$ for ACh and $\tau_{\mathrm{f}}=73.3 \mathrm{~ms}$ and $\tau_{\mathrm{s}}=1028.0 \mathrm{~ms}$ for nicotine. Comparisons of peak current amplitudes ( $\mathrm{pA} / \mathrm{pF}$; ordinate) for responses to ACh $(67.2 \pm 22.6 \mathrm{pA} / \mathrm{pF}$; cross-hatched bar, $n=8)$ or nicotine $(76.3 \pm 14.2$ $\mathrm{pA} / \mathrm{pF}$; solid bar, $n=10)$ plotted as a bar graph (C) show no significant difference $(P=0.728)$. Comparisons of time constants (ms; ordinate) for the decay of the peak current responses during a 4-s exposure to $\mathrm{ACh}$ (cross-hatched bars) or nicotine (solid bars) show that the slower rate of desensitization $\left(\tau_{\mathrm{s}}\right)$ in response to ACh pulses $(701.3 \pm 57.1 \mathrm{~ms})$ is faster than that for the slower rate of desensitization in response to nicotine pulses (930.0 $\pm 61.1 \mathrm{~ms} ; P=0.017,{ }^{\mathrm{b}} P<0.05$ ), whereas $\tau_{\mathrm{f}}$ values are more comparable $(60.7 \pm 8.3 \mathrm{~ms}$ for $\mathrm{ACh}, 73.5 \pm 7.9 \mathrm{~ms}$ for nicotine; $P=0.283)$.

peak current amplitudes for responses to ACh $(67.2 \pm 22.6$ $\mathrm{pA} / \mathrm{pF}, n=8$ cells $)$ or nicotine $(76.3 \pm 14.2 \mathrm{pA} / \mathrm{pF}, n=10$; Figure $2 \mathrm{C})$ revealed no significant difference $(P=0.728)$ in efficacy for these agonists, even before adjustment for cell size (2246 $\pm 755 \mathrm{pA}$ for ACh responses, $2737 \pm 695 \mathrm{pA}$ for nicotine responses). Time constants ( $\tau$ ) for the decay of the inward current response during $4 \mathrm{~s}$ of exposure to $\mathrm{ACh}$ or nicotine fit to bi-exponential expressions show that the fast component of acute desensitization induced by ACh $\left(\tau_{\mathrm{f}}=60.7 \pm 8.3\right.$ $\mathrm{ms}, n=8)$ tended to be faster $(P=0.283)$ than that induced by nicotine exposure $\left(\tau_{\mathrm{f}}=73.5 \pm 7.9 \mathrm{~ms}, n=10\right)$. Additionally, the slow component of desensitization to ACh pulses $\left(\tau_{\mathrm{s}}=701 \pm 57 \mathrm{~ms}\right)$ was significantly faster $(P=0.017)$ than that 
induced by acute nicotine challenge $\left(\tau_{\mathrm{s}}=930 \pm 61 \mathrm{~ms}\right.$; Figure 2D). Although the kinetics of the acute responses to the agonist for unlifted cells was generally slower than that for lifted cells, the fast component of desensitization induced by $\mathrm{ACh}$ $\left(\tau_{\mathrm{f}}=209 \pm 14 \mathrm{~ms}, n=30\right)$ again tended to be faster $(P=0.43)$ than that induced by nicotine exposure $\left(\tau_{\mathrm{f}}=240 \pm 35 \mathrm{~ms}\right.$, $n=19)$; the slow component of desensitization to ACh pulses $\left(\tau_{\mathrm{s}}=2035 \pm 323 \mathrm{~ms}\right)$ also tended to be faster $(P=0.25)$ than that induced by acute nicotine challenge $\left(\tau_{s}=3817 \pm 1473\right.$ $\mathrm{ms})$.

In order to determine an interpulse interval in the recording of a $4 \beta 2$-nAChR responses from transfected SH-EP1 cells that would minimize or eliminate effects carried over from earlier drug applications, we used a protocol in which a series of six 1-s pulses of exposure to $1 \mathrm{mmol} / \mathrm{L} \mathrm{ACh}$ was delivered at a varying interpulse interval with extracellular medium applied between drug applications (Figure 3). The peak current amplitudes from successive exposures of unlifted cells to the agonist were normalized to the initial peak current amplitude. The data indicated that there was a significant rundown of the peak current amplitude if the interpulse interval was $1 \mathrm{~s}(73.1 \% \pm 3.5 \%$ of control, $n=6), 5 \mathrm{~s}(83.6 \% \pm 1.9 \%$ of control), or $10 \mathrm{~s}(84.0 \% \pm 0.9 \%$ of control $)$ but not $20 \mathrm{~s}$ (93.6\% $\pm 2.4 \%$ of control, $n=8, P>0.05$ ). Thus, whenever possible, we assessed the effects of the acute desensitization of human $\alpha 4 \beta 2$-nAChRs due to a 1 -s pulse of $1 \mathrm{mmol} / \mathrm{L} \mathrm{ACh}$ at interpulse intervals of $20 \mathrm{~s}$ or more.

In studies to define the extent and kinetics of the recovery of human $\alpha 4 \beta 2$-nAChRs from acute desensitization, we evaluated peak whole-cell current responses after exposure to ACh or nicotine for specific periods of time to induce acute desensitization. Data from studies using lifted and unlifted cells were combined. After exposure to a fully efficacious, desensitizing pulse of $1 \mathrm{mmol} / \mathrm{L}$ ACh for $1 \mathrm{~s}$, SH-EP1-h $\alpha 4 \beta 2$ cells were then exposed to a 1-s test pulse of $1 \mathrm{mmol} / \mathrm{L} \mathrm{ACh}$ at different intervals between the paired pulses from $0.5 \mathrm{~s}$ to $80 \mathrm{~s}$ (Figure 4A). The interval between each group of paired, desensitizing test pulses was longer than one min. Test pulse peak current amplitudes increased with the interpulse interval, and test responses were indistinguishable from the initial response for a wash interval for $20 \mathrm{~s}(97.3 \% \pm 2.4 \%$ of control, $n=6, P=0.312$ ) or more, consistent with the data shown in Figure 3. Plots of normalized peak current responses as a function of the interpulse interval were fit equally well by either mono- $\left(r^{2}=0.81\right)$ or bi- $\left(r^{2}=0.81\right)$ exponential equations, yielding $\tau=1.66 \pm 0.26 \mathrm{~s}$ ( $53 \%$ recovery from a residual of $45 \%$ of control function) or $\tau_{\mathrm{f}}=1.59 \pm 0.65 \mathrm{~s}$ ( $51 \%$ recovery) and $\tau_{\mathrm{s}}=10.8 \pm 129 \mathrm{~s}(2 \%$ recovery; Figure $4 \mathrm{C}$; Table 1$)$. Recovery from a 1 -s desensitizing pulse of $0.1 \mathrm{mmol} / \mathrm{L}$ nico-
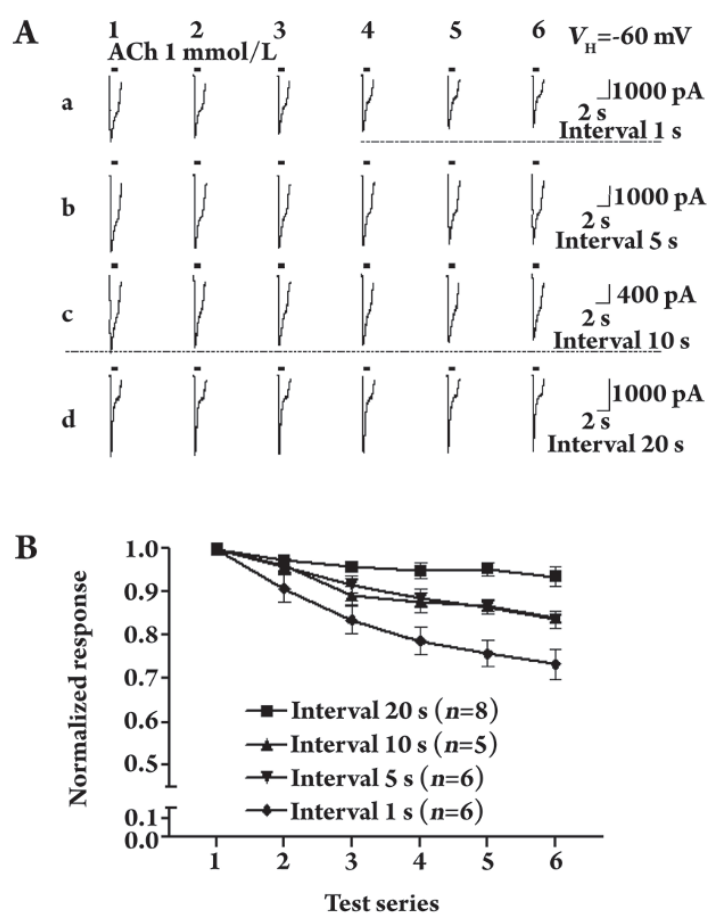

Figure 3. Evaluation of $\alpha 4 \beta 2-n A C h R$ functional rundown. (A) Typical whole-cell current traces are illustrated for responses to 1-s pulses of $1 \mathrm{mmol} / \mathrm{L} \mathrm{ACh}$ applied at interpulse intervals of $1 \mathrm{~s} \mathrm{(a),} 5$ $\mathrm{s}(\mathrm{b}), 10 \mathrm{~s}$ (c), or $20 \mathrm{~s}$ (d) applied at a holding potential of $-60 \mathrm{mV}$. Recordings were made using different cells for specific interpulse intervals (note the different current calibration scales). (B) Average peak current amplitudes (normalized to the respective amplitude of the response to the first agonist challenge; ordinate) for recordings from the indicated numbers of cells and for the specified interpulse intervals ( $1 \mathrm{~s}, \boldsymbol{\nabla} ; 5 \mathrm{~s}, \boldsymbol{\nabla}$; $10 \mathrm{~s}, \boldsymbol{\Delta} ; 20 \mathrm{~s}, \boldsymbol{\square}$ ) are shown as a function of the test number (abscissa), illustrating significant rundown (note the break in the $y$-axis) for interpulse intervals of $10 \mathrm{~s}$ or shorter. These findings validate the choice of a 20-s interpulse interval for studies of the recovery from desensitization.

tine was slower, and full recovery of human $\alpha 4 \beta 2$-nAChRs had not occurred even $80 \mathrm{~s}$ after drug removal $(88.4 \% \pm 1.7 \%$ of control, $n=11, P<0.001$, Figure $4 \mathrm{~B}$ ). Plots of the normalized peak current amplitude for different interpulse intervals fit equally well by either mono- $\left(r^{2}=0.75\right)$ or bi- $\left(r^{2}=0.76\right)$ exponential equations yielded $\tau=6.17 \pm 0.69 \mathrm{~s}$ (55\% recovery from a residual of $32 \%$ of control function) or $\tau_{\mathrm{f}}=1.00 \pm 1.24$ s $\left(11 \%\right.$ recovery) and $\tau_{s}=9.34 \pm 3.45$ s ( $46 \%$ recovery; Figure $4 \mathrm{D}$; Table 1) as time constants for the recovery of $\alpha 4 \beta 2$ $\mathrm{nAChRs}$ from the acute desensitization induced by $1 \mathrm{~s}$ of nicotine exposure at $0.1 \mathrm{mmol} / \mathrm{L}$. Overall, recovery from acute desensitization induced by $1 \mathrm{~s}$ of agonist exposure was much slower for induction by nicotine than $\mathrm{ACh}$ when fit to the mono-exponential expression $(P=0.0002$ for differences in $\tau)$. However, fits of the data to bi-exponential expressions 
Table 1. Rate constants for recovery from desensitization for $\alpha 4 \beta 2$-nAChR. Rate constants for recovery of human $\alpha 4 \beta 2$-nAChR function after desensitizing exposure to $1 \mathrm{mmol} / \mathrm{L} \mathrm{ACh}$ or $0.1 \mathrm{mmol} / \mathrm{L}$ nicotine for the specified duration of desensitizing pulse (column 1$)$ were obtained from studies illustrated in Figures 4-6 based on fits to mono-exponential or bi-exponential equations as indicated. Values for rate constants (1/s) are expressed as mean \pm SEM for the number of cells per condition provided in the narrative. Values in square brackets above the slash in columns 2 or 3 or in column 4 represent the extent of functional recovery from desensitization as a percentage of control levels, and values in square brackets below the slash in columns 2 or 3 represent the initial level of function as a percentage of control immediately after the end of the desensitizing pulse.

\begin{tabular}{lrcrc}
\hline $\begin{array}{l}\text { Drug and desensitizing } \\
\text { pulse duration }\end{array}$ & & $\begin{array}{c}\text { Mono-exponential } \\
k(1 / \mathrm{s})(\% \text { recovery })\end{array}$ & $k f(1 / \mathrm{s})(\%$ recovery) & \multicolumn{2}{c}{ Bi-exponential } \\
& & $0.417 \pm 0.063(53 / 45)$ & $0.437 \pm 0.178(51 / 45)$ & $0.0639 \pm 0.7634(2)$ \\
ACh $1 \mathrm{mmol} / \mathrm{L}$ & $1 \mathrm{~s}$ & $0.168 \pm 0.016(87 / 3)$ & $0.293 \pm 0.102(61 / 3)$ & $0.0335 \pm 0.0273(29)$ \\
& $30 \mathrm{~s}$ & $0.0298 \pm 0.0063(80 / 0)$ & $0.147 \pm 0.142(40 / 0)$ & $0.00924 \pm 0.00666(44)$ \\
Nico $0.1 \mathrm{mmol} / \mathrm{L}$ & $180 \mathrm{~s}$ & $0.112 \pm 0.013(55 / 32)$ & $0.691 \pm 0.816(11 / 32)$ & $0.0742 \pm 0.0274(46)$ \\
& $1 \mathrm{~s}$ & $0.0647 \pm 0.0028(87 / 4)$ & $0.0837 \pm 0.0144(70 / 4)$ & $0.0128 \pm 0.0145(23)$ \\
& $30 \mathrm{~s}$ & $0.0115 \pm 0.0012(62 / 0)$ & $0.0117 \pm 0.0050(61 / 0)$ & $0.000582 \pm 0.1297(3)$ \\
\hline
\end{tabular}

revealed that the difference was not due to differences in fast or slow rate constants but rather to a larger proportion of recovery occurring through the slower process after nicotine exposure (Table 1).

Other studies involved the exposure of SH-EP1-ha4 32 cells to 30 -s desensitizing pulses of $1 \mathrm{mmol} / \mathrm{L} \mathrm{ACh}$ or 0.1 $\mathrm{mmol} / \mathrm{L}$ nicotine followed by test pulses after interpulse intervals of 0.5 to $200 \mathrm{~s}$ (Figure 5). The interval between each group of paired pulses was longer than two minutes. After $30 \mathrm{~s}$ of initial exposure to $1 \mathrm{mmol} / \mathrm{L} \mathrm{ACh}$, a roughly
A
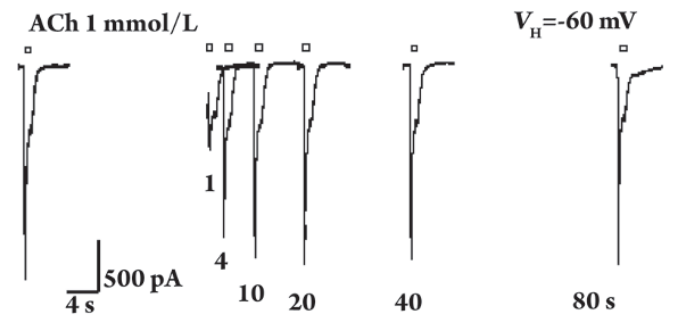

C

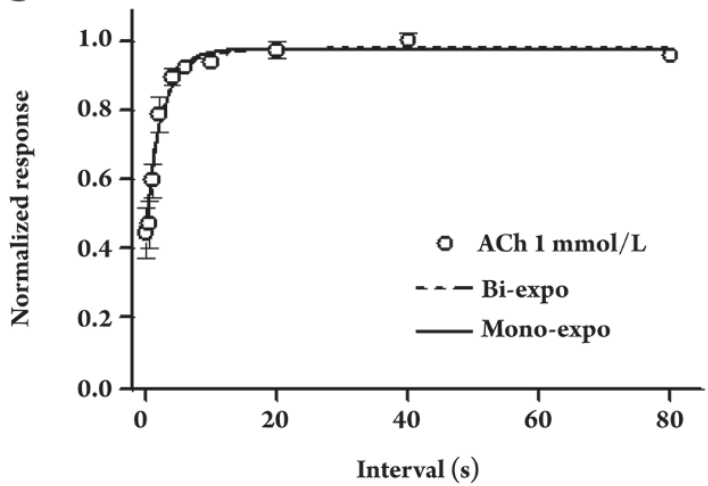

B Nico $0.1 \mathrm{mmol} / \mathrm{L}$
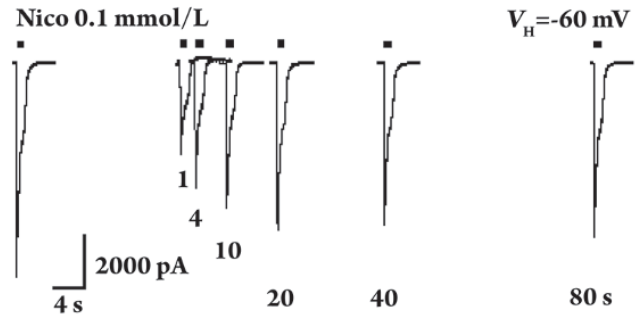

$80 \mathrm{~s}$

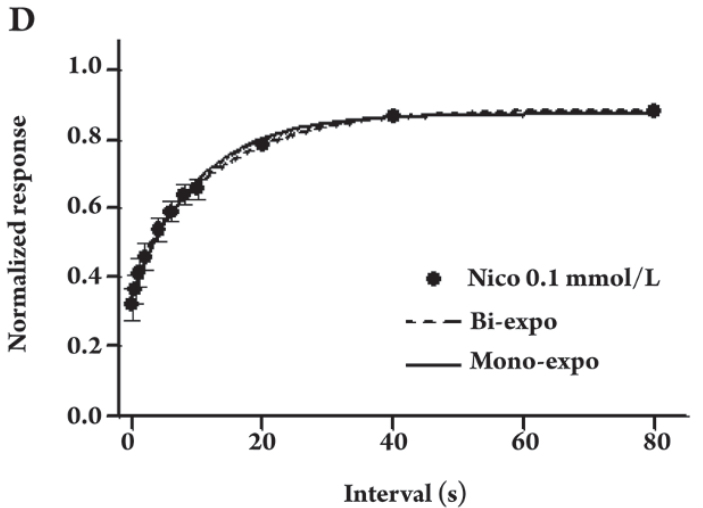

Figure 4. Time course for $\alpha 4 \beta 2$-nAChR recovery from desensitization after a 1-s desensitizing pulse. Typical whole-cell current responses are illustrated for SH-EP1-ha4 32 cells subjected to paired 1-s desensitizing pulses of $1 \mathrm{mmol} / \mathrm{L} \mathrm{ACh} \mathrm{(A)} \mathrm{or} 0.1 \mathrm{mmol} / \mathrm{L}$ nicotine (B) (only one typical response to the desensitizing pulse is indicated) followed by a 1-s test pulse of the same agonist and dose after the indicated interpulse interval. Recordings (note the time and current amplitude calibration bars) were obtained at a holding potential of - $60 \mathrm{mV}$. Averaged peak current amplitudes for responses to test pulses normalized to the amplitude of the desensitizing pulse response (ordinate) are plotted for responses to ACh (C; $\mathrm{O})$ or nicotine $(\mathrm{D} ; \mathbf{O})$ as a function of the interpulse interval $(\mathrm{s}$; abscissa). Data were fit to mono- (solid lines) or bi- (dashed lines) exponential equations, yielding values for the extent of desensitization, extent of recovery, and rate constants for recovery indicated in the text and tables. 
A

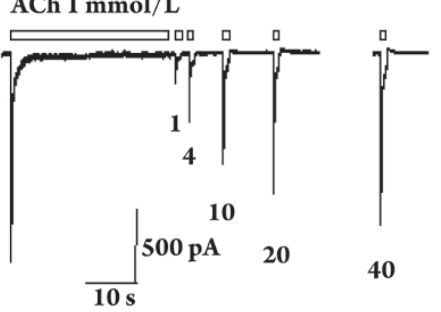

C

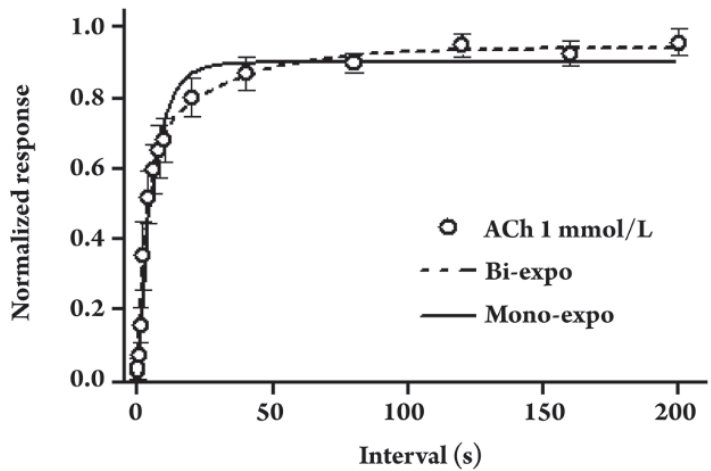

B
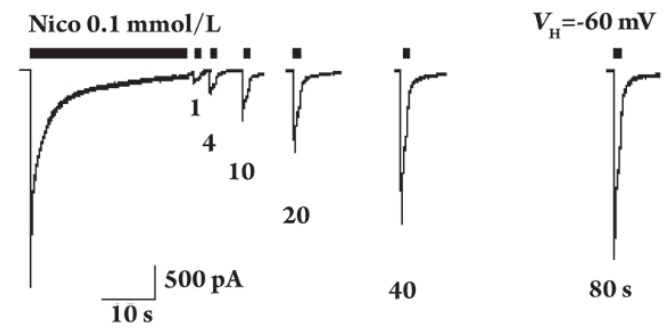

D

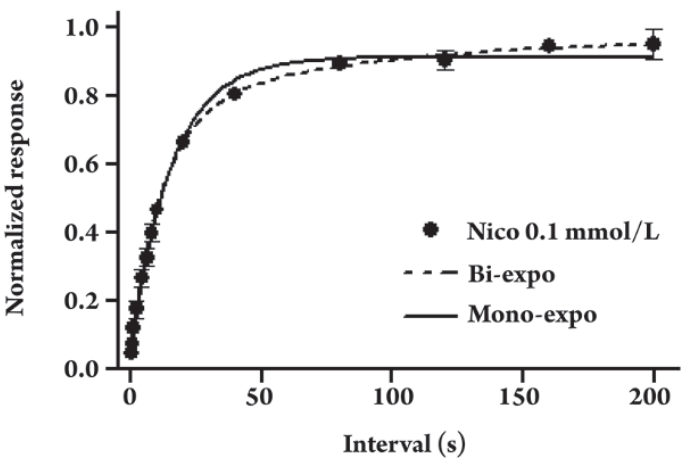

Figure 5. Time course for $\alpha 4 \beta 2$-nAChR recovery from desensitization after a 30-s desensitizing pulse. Typical whole-cell current responses are illustrated for SH-EP1-ha4 32 cells subjected to paired 30-s desensitizing pulses of $1 \mathrm{mmol} / \mathrm{L}$ ACh (A) or $0.1 \mathrm{mmol} / \mathrm{L}$ nicotine (B) (only one typical response to the desensitizing pulse is indicated) followed by 1-s test pulses of the same agonist and dose after the indicated interpulse interval. Recordings (note the time and current amplitude calibration bars) were obtained at a holding potential of - $60 \mathrm{mV}$. Averaged peak current amplitudes for responses to test pulses normalized to the amplitude of the desensitizing pulse response (ordinate) are plotted for responses to ACh (C; $\mathrm{O})$ or nicotine $(\mathrm{D} ; \mathbf{O})$ as a function of the interpulse interval (s; abscissa). Data were fit to mono- (solid lines) or bi- (dashed lines) exponential equations, yielding values for the extent of desensitization, extent of recovery, and rate constants for recovery indicated in the text and tables.

120 -s incubation in drug-free solution was required for the amplitude of the response to the test pulse to recover ( $94.9 \% \pm 3.4 \%$ of control, $n=5, P=0.21$; Figure $5 \mathrm{~A}$ ). Results plotted as normalized peak current responses at different interpulse intervals fit by a mono-exponential expression $\left(r^{2}=0.86\right)$ yielded $\tau=4.14 \pm 0.40 \mathrm{~s}$ ( $87 \%$ recovery from a residual of $3 \%$ of control function), but the data were fit significantly better $(P=0.037)$ to a bi-exponential expression $\left(r^{2}=0.87\right)$ yielding $\tau_{\mathrm{f}}=2.37 \pm 0.82 \mathrm{~s}(61 \%$ recovery $)$ and $\tau_{\mathrm{s}}=20.8 \pm 17.0 \mathrm{~s}$ (29\% recovery; Figure 5C; Table 1). The recovery of $\alpha 4 \beta 2$-nAChR function after acute desensitization induced by $30 \mathrm{~s}$ of exposure to $0.1 \mathrm{mmol} / \mathrm{L}$ nicotine was slower than that after ACh exposure and was incomplete until $120 \mathrm{~s}$ after drug washout $(94.5 \% \pm 2.1 \%$ of control, $n=6$, Figure 5B). Plots of the normalized peak current amplitude for different interpulse intervals fit by the mono-exponential expression $\left(r^{2}=0.97\right)$ yielded $\tau=10.7 \pm 0.47 \mathrm{~s}$ ( $87 \%$ recovery from a residual of $4 \%$ of control function), but the data were fit better $(P=0.012)$ with the bi-exponential expression $\left(r^{2}=0.98\right)$ yielding $\tau_{\mathrm{f}}=8.28 \pm 1.42 \mathrm{~s}(70 \%$ recovery $)$ and $\tau_{\mathrm{s}}=54.3 \pm 61.1 \mathrm{~s}$ (23\% recovery; Figure 5D; Table 1). Both mono- and bi-exponential analyses indicated that the time constants for the recovery from nicotine-induced desensitization were longer than those for inactivation induced by ACh (Table 1). Recovery from effects of a given agonist was slower after 30-s desensitizing exposure than after 1-s exposure.

A variation on the protocol for assessing the recovery from desensitization was employed to aid in the study of the functional inactivation induced by longer-term agonist exposure. Following a $180 \mathrm{~s}$, fully-desensitizing pulse of 1 $\mathrm{mmol} / \mathrm{L} \mathrm{ACh}$, test pulses of $1 \mathrm{mmol} / \mathrm{L} \mathrm{ACh}$ for 1-s duration were applied at interpulse intervals of $20 \mathrm{~s}$ or greater. This paradigm enabled the successive recording of peak current responses without rundown, and our earlier studies indicated that any acute desensitization induced by 1-s ACh exposures recovered within $20 \mathrm{~s}$ after drug washout. After the 180-s desensitizing exposure to $1 \mathrm{mmol} / \mathrm{L} \mathrm{ACh}$, incomplete recovery of function occurred even after $540 \mathrm{~s}$ of incubation in the drug washout period $(83.9 \% \pm 11.8 \%$ of control, $n=6$; Figure $6 \mathrm{~A}$ ). In contrast, maximal recovery seemed to be achieved after $360 \mathrm{~s}$ in the drug-free solution. Plots of the data fit by 
A ACh $1 \mathrm{mmol} / \mathrm{L}$

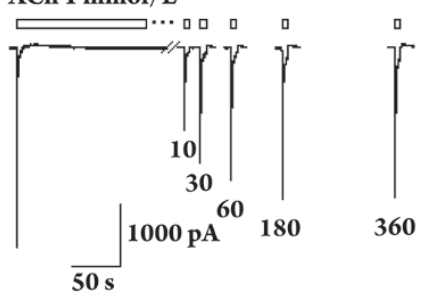

$\mathbf{C}$

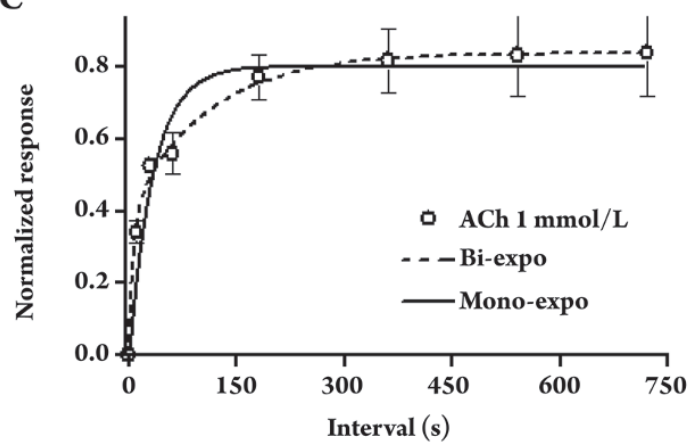

B Nico $0.1 \mathrm{mmol} / \mathrm{L}$
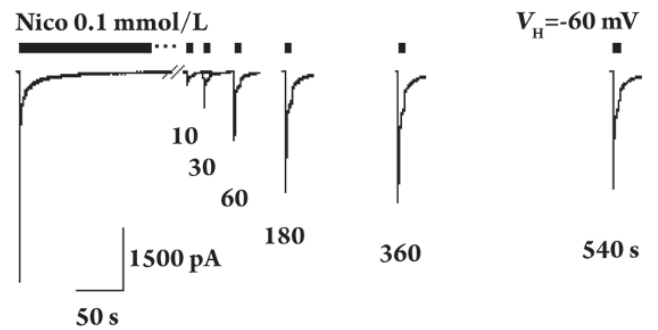

360

$540 \mathrm{~s}$
D

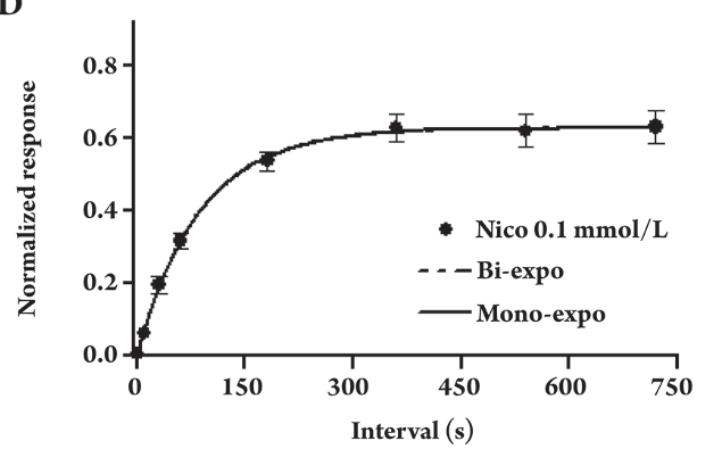

Figure 6. Time course for $\alpha 4 \beta 2$-nAChR recovery from desensitization after a 180 -s desensitizing pulse. Typical whole-cell current responses are illustrated for SH-EP1-h $\alpha 4 \beta 2$ cells subjected to paired 180-s desensitizing pulses of $1 \mathrm{mmol} / \mathrm{L} \mathrm{ACh} \mathrm{(A)} \mathrm{or} 0.1 \mathrm{mmol} / \mathrm{L}$ nicotine (B) (only one typical response to the desensitizing pulse is indicated) followed by 1-s test pulses of the same agonist and dose after the indicated interpulse interval. Recordings (note the time and current amplitude calibration bars) were obtained at a holding potential of - $60 \mathrm{mV}$. Averaged peak current amplitudes for responses to test pulses normalized to the amplitude of the desensitizing pulse response are plotted for responses to ACh (C; $\bigcirc$ ) or nicotine $(\mathrm{D} ; \mathrm{O})$ as a function of the interpulse interval. Data were fit to mono- (solid lines) or bi- (dashed lines) exponential equations, yielding values for the extent of desensitization, extent of recovery, and rate constants for recovery indicated in the text and tables.

either mono- $\left(r^{2}=0.75\right)$ or bi- $\left(r^{2}=0.78\right)$ exponential equations (where the $P$-value for the improved fit to the bi-exponential equation was 0.053 ) revealed that the recovery from desensitization induced by $180 \mathrm{~s}$ of exposure to $1 \mathrm{mmol} / \mathrm{L}$ ACh (Figure 6C) also was much slower $(\tau=23.2 \pm 4.8 \mathrm{~s}$ for $80 \%$ functional recovery or $\tau=4.71 \pm 4.51 \mathrm{~s}$ for $40 \%$ recovery and $\tau_{\mathrm{s}}=75.0 \pm 53.9 \mathrm{~s}$ for $44 \%$ recovery) than that from either 1-s or 30-s desensitizing pulses (Table 1). Recovery from the acute desensitization of human $\alpha 4 \beta 2$-nAChRs induced by $180 \mathrm{~s}$ of exposure to $0.1 \mathrm{mmol} / \mathrm{L}$ nicotine also was slower and less complete (reaching a maximum of $63.2 \% \pm 4.7 \%$ of control with no statistically significant difference between 360 and $720 \mathrm{~s}$ of recovery in drug-free solution) than that seen following shorter-term desensitizing pulses with nicotine or any of the desensitizing protocols using ACh (Figure 6B). Fits of the data to a mono-exponential expression $\left(r^{2}=0.93\right)$ yielded $\tau=60.4 \pm 6.5 \mathrm{~s}$ ( $62 \%$ recovery) and were essentially indistinguishable from bi-exponential fits $\left(r^{2}=0.93\right)$ because of the dominance of the faster phase of functional recovery $\left(\tau_{\mathrm{f}}=59.4 \pm 28.9 \mathrm{~s}\right.$ for $61 \%$ recovery and $\tau_{\mathrm{s}}=600 \pm 106,300 \mathrm{~s}$ for 3\% recovery; Figure 6D; Table 1).

Plots of the rate constants for the recovery from acute desensitization derived from the data for ACh or nicotine treatments as a function of desensitizing pulse time [for lifted or unlifted cells or all cells together and based on mono- or bi-exponential fits (Figure 7)] clearly depict some features of the data. First, there were no significant or systematic differences in the results, regardless of whether they were obtained using lifted or unlifted cells (Figure 7). This finding thus validates our decision to combine the data for the analysis of the recovery from acute desensitization, despite the clear differences in the kinetics of acute desensitization (Figure 1). It again suggests that the different kinetics of acute desensitization with time constants in the ms range reflect primarily differences in cell perfusion rather than fundamental differences in $\alpha 4 \beta 2$-nAChR properties. However, the slower kinetics of recovery from desensitization are insensitive to whether recordings were made from cells in the lifted or attached mode. Second, mono-exponential fits indicate that the rate constants for the recovery of function after desensitization by either agonist become progressively smaller with increased time of agonist exposure during the desensitizing pulse and are smaller for nicotine- than for ACh-induced desensitization (Figure 7A; Table 1). That pattern is repeated for bi-exponential fits to the data, with the exception that the rate constants for the recovery from nicotine-induced desen- 
Rate constants for recovery of human

$\alpha 4 \beta 2-n A C h R$ from acute desensitization
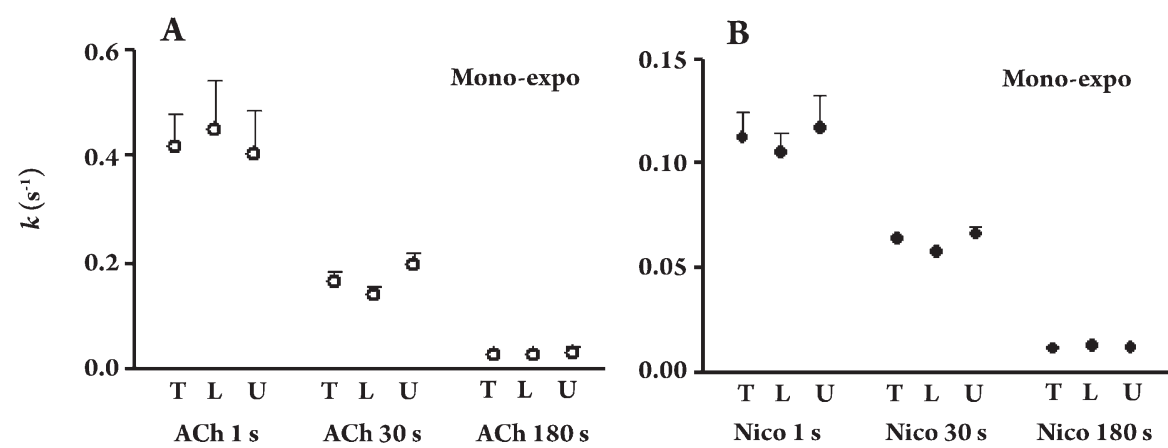

C

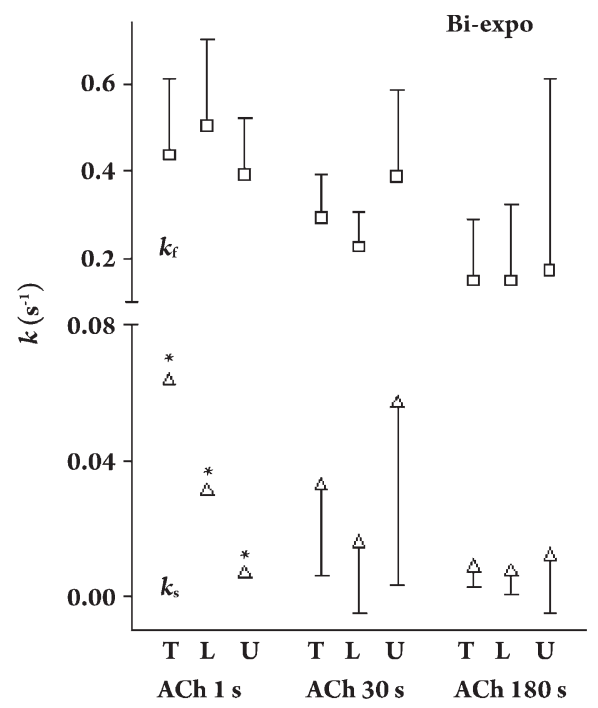

D

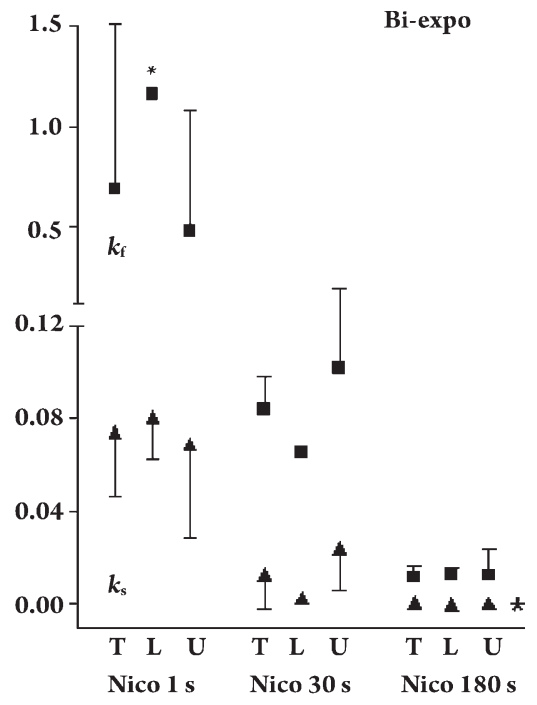

Figure 7. Comparisons of rate constants for the recovery from desensitization. From the data illustrated in Figures 4-6, rate constants were determined and are plotted here $(1 / \mathrm{s}$, mean \pm SEM. * denotes values where large error bars are omitted for clarity; ordinates) for the recovery from desensitization derived from monoexponential fits to the results for responses to $\mathrm{ACh}(\mathrm{A} ; \mathrm{O})$ or nicotine $(\mathrm{B} ; \mathbf{O})$ or for the fast $\left(k_{\mathrm{f}}\right)$ or slow $\left(k_{\mathrm{s}}\right)$ phases of recovery determined from fits of the results to biexponential functions for responses to ACh (C; $\square$ or $\triangle$, respectively) or nicotine (D; $\boldsymbol{\square}$ or $\boldsymbol{\Delta}$, respectively). Data are presented for all (total; T), lifted (L), or unlifted (U) cells and for the specified interpulse intervals $(1,30$, or $180 \mathrm{~s}$; abscissas). The decrease in the rate constant for the recovery from desensitization with increasing desensitizing pulse duration is evident for both agonists, regardless of whether mono- or bi-exponential fits are applied and whether results are from lifted or unlifted cells. sitization are larger than those for the $\mathrm{ACh}$-induced process for 1-s desensitizing pulses (Figure 7B; Table 1). However, the fast component of recovery from 1-s desensitization is only $20 \%$ of the total recovery after nicotine exposure, but it is more than $95 \%$ of the total recovery after ACh-induced desensitization. In fact, it could be argued that nicotine's effects are unique in that the slower rate of recovery from the desensitization induced by $1 \mathrm{~s}$ of nicotine exposure is like the faster rate of recovery following 30-s nicotine exposure. Similarly, the slower rate of recovery from the desensitization induced by $30 \mathrm{~s}$ of nicotine exposure is like the faster rate of recovery following $180 \mathrm{~s}$ of nicotine exposure. Viewed from another perspective, if the recovery from nicotine desensitization data were binned into segments defined by rates constants of $\sim 0.7,0.08,0.012$, and $0.0006 \mathrm{~s}^{-1}$, the percentage of total recovery falling into those bins would be $11 \% / 57 \%$, $46 \% / 57 \%, 0 \%$, and $0 \%$ after a 1 -s desensitizing pulse, $0 \%$,
$70 \% / 93 \%, 23 \% / 93 \%$, and $0 \%$ after a 30 -s desensitizing pulse, and $0 \%, 0 \%, 61 \% / 64 \%$, and $3 \% / 64 \%$ after a 180 -s desensitizing pulse.

\section{Discussion}

The principal findings of the present study on the recovery of $\alpha 4 \beta 2-n A C h R s$ from desensitization are as follows: (1) both the onset of and the recovery from desensitization for $\alpha 4 \beta 2$-nAChRs induced by maximally efficacious and comparably potent doses of $1 \mathrm{mmol} / \mathrm{L} \mathrm{ACh}$ or $0.1 \mathrm{mmol} / \mathrm{L}$ nicotine occur as bi-exponential processes and (2) recovery of $\alpha 4 \beta 2-n A C h R s$ from desensitization is time-dependent and agonist-dependent, reflecting longer half-times for the recovery from desensitization for longer periods of agonist exposure during the desensitizing pulse and slower recovery from desensitization induced by nicotine exposure compared 
with ACh exposure of the same duration.

For agonist challenge pulses of $0.5 \mathrm{~s}$ or less, inward current decay from peak levels fit to a mono-exponential function gave time constants similar to $\tau \mathrm{f}$ for bi-exponential fits, and errors were very large in estimates of $\tau$ s. However, evidence for a slower, second component of the onset of $\alpha 4 \beta 2$ $\mathrm{nAChR}$ desensitization arose from studies of the effects of agonist pulses $1-4 \mathrm{~s}$ in duration. These findings are most readily explained by the existence of a single receptor type undergoing conversion to two desensitized states. Although some studies, including those employing single channel recording, using very short periods of agonist application are indicative of a single phase of $\mathrm{nAChR}$ desensitization ${ }^{[22,23]}$, others also revealed the presence of a biphasic process of desensitization ${ }^{[18,24-27]}$. The current studies indicate that human $\alpha 4 \beta 2$-nAChRs have half-times for fast and slow desensitization upon exposure to ACh or nicotine of about 60-75 ms and 700-950 ms, respectively. These times are similar to analogous half-times for the fast and slow onset of desensitization of presumed $\alpha 3 \beta 4^{*}$-nAChRs in rat chromaffin cells (110 and $660 \mathrm{~ms})^{[25]}$ or for mouse muscle-type nAChR (30 and $2800 \mathrm{~ms})^{[27]}$. Thus, multiple phases for the onset of desensitization may be characteristic of many nAChR subtypes.

Evidence for two components in the recovery from agonist-induced desensitization of human $\alpha 4 \beta 2$-nAChRs arose when the desensitizing pulse was lengthened beyond $1 \mathrm{~s}$ for ACh exposure or reached any of the nicotine exposure protocols used. These findings also could be explained if there were a single population of receptors converting to more than one desensitized state. These conditions for inducing conversion to a second desensitized state are not frequently found in electrophysiological studies. When mouse muscletype $\mathrm{nAChRs}$ are exposed to an agonist for periods adequate to reveal a slower phase of desensitization onset, however, the slower process of recovery also is observed ${ }^{[27]}$. Isotopic ion flux-based studies and electrophysiological recording analyses have long noted a slower phase of recovery from "desensitization" induced by the protracted exposure of muscle-type, $\alpha 3 \beta 4-$, or $\alpha 4 \beta 2$-nAChRs to a nicotinic agonist $^{[2,19,28,29]}$.

Regardless of whether recovery from desensitization is fit by mono- or bi-exponential processes, the current findings indicate that the rate of recovery slows as a function of increased agonist exposure duration. Along with results of studies of muscle-type nAChR desensitization ${ }^{[1]}$, these findings suggest that many distinctive states of desensitization exist and that greater depths of desensitization are achieved when the duration of agonist exposure increases. This sug- gests that rates of recovery from desensitization are not limited by rates of recovery from less deeply, and perhaps initially induced, desensitized forms of $\alpha 4 \beta 2-n A C h R$. Further, those rates of recovery from more deeply desensitized states dominate when there has been a transition through more than one desensitized state. With regard to the effects of $\mathrm{ACh}$, there is no evidence that these states are discrete; none of the rate constants $\left(k_{\mathrm{s}}\right)$ for the slower phase of recovery from desensitization match rate constants $\left(k_{\mathrm{f}}\right)$ for the faster phase of recovery observed after longer exposure to ACh. However, $k_{\mathrm{s}}$ values for a 1-s exposure to nicotine are indistinguishable from $k_{\mathrm{f}}$ values for a 30-s exposure to nicotine, and ks values for a 30-s exposure to nicotine are close to $k_{\mathrm{f}}$ values for a 180 -s exposure to nicotine. Thus, it is possible that conditions of agonist exposure time could be found that would reveal discrete states of desensitization in response to ACh exposure. Given that time-dependent pore dilation is a property of P2X ATP-gated ion channels ${ }^{[30,31]}$, it is possible that time-dependent pore constriction of $\mathrm{nAChR}$ channels could account for the different states of desensitization; this would be particularly applicable if the rates of recovery from those states lie on a continuum rather than in discrete sets.

Once again ${ }^{[1]}$, we have found that rates of recovery from desensitization by an agonist at a maximally efficacious dose applied for a given period of time are agonist-dependent. Whereas ACh induced deeper desensitization of muscletype nAChRs than did nicotine, however, rates of $\alpha 4 \beta 2$ $\mathrm{nAChR}$ recovery from desensitization were slower following nicotine compared with ACh exposure (Table 2). This finding suggests that more deeply desensitized states (or more of the deeply desensitized states) of $\alpha 4 \beta 2$-nAChRs are more effectively induced by nicotine than ACh. We previously considered the possibility that differences in agonist efficacy and/or potency could influence these findings, but ACh and nicotine are equally efficacious at the $\alpha 4 \beta 2$-nAChR. Additionally, their potencies differ by only a factor of 2 when assessed using ion flux assays $\left(\mathrm{ACh} \mathrm{EC}_{50}=1.7 \mu \mathrm{mol} / \mathrm{L}\right.$, nicotine $\left.\mathrm{EC}_{50}=0.85 \mu \mathrm{mol} / \mathrm{L}\right)^{[20]}$. Therefore, the degrees of desensitization produced by the two agonists should be very similar. Perhaps the slower rate of recovery from nicotineinduced desensitization is due to the slower dissociation of higher affinity nicotine from $\alpha 4 \beta 2$-nAChRs or to its entry into and slow release from recorded cells ${ }^{[1-3]}$. However, if intracellular sequestration and release are important in the current studies, they probably also are important in vivo in cases where medicinal or tobacco nicotinic or related agents modulate the state of $\mathrm{nAChR}$ activation/desensitization. In this regard, it is notable that chronic exposure to nicotine at doses in the $100 \mathrm{nmol} / \mathrm{L}$ range, as found in the plasma of 
Table 2. Comparison of time constants for recovery from desensitization for $\alpha 4 \beta 2$-nAChR and muscle-type nAChR. Time constants for recovery of human $\alpha 4 \beta 2$-nAChR function after desensitizing exposure to $1 \mathrm{mmol} / \mathrm{L} \mathrm{ACh}$ or $0.1 \mathrm{mmol} / \mathrm{L}$ nicotine obtained as indicated in Figure $4-6$ are presented here and compared to parameters for recovery from desensitization of muscle-type ( $\alpha 1-)$ nAChR (Reitstetter et al, 1999, Ref 1). Data for muscle-type $\mathrm{nAChR}$ were fit to a single exponential, and results for $\alpha 4 \beta 2$-nAChR also are fit to a single exponential processes to facilitate comparisons. Values are expressed as mean \pm SEM for the number of cells per condition given in parentheses.

\begin{tabular}{|c|c|c|c|c|}
\hline \multirow{3}{*}{$\begin{array}{l}\text { Desensitizing } \\
\text { pulse duration }\end{array}$} & \multicolumn{2}{|c|}{$1 \mathrm{mmol} / \mathrm{L} \mathrm{ACh}$} & \multicolumn{2}{|c|}{$0.1 \mathrm{mmol} / \mathrm{L}$ nicotine } \\
\hline & $\alpha 1-\mathrm{nAChR}^{*}$ & $\alpha 4 \beta 2-n A C h R$ & a1-nAChR* & $\alpha 4 \beta 2-n A C h R$ \\
\hline & $\tau(\mathrm{s})$ & $\tau(\mathrm{s})$ & $\tau(s)$ & $\tau(\mathrm{s})$ \\
\hline $1 \mathrm{~s}$ & $31.5 \pm 4.0(6)$ & $1.66 \pm 0.25(6)$ & $18.8 \pm 2.6(6)$ & $6.17 \pm 0.69(11)$ \\
\hline $30 \mathrm{~s}$ & $113 \pm 21(4)$ & $4.13 \pm 0.40(6)$ & $50.0 \pm 5.4(4)$ & $10.7 \pm 0.5(6)$ \\
\hline $180 \mathrm{~s}$ & $534 \pm 84(8)$ & $23.2 \pm 4.9(6)$ & $282 \pm 54(8)$ & $60.4 \pm 6.5(6)$ \\
\hline
\end{tabular}

* Results from Reitstetter et al, 1999, Ref 1 . All differences across subtypes are statistically significant.

tobacco users, induces negligible loss of muscle-type $\mathrm{nAChR}$ function $^{[32]}$ but roughly $50 \%$ loss of $\alpha 4 \beta 2-n A C h R$ function $^{[2]}$ after no or a few minutes of recovery. Thus, it is the combination of the agonist desensitizing potency and rates of recovery from desensitization that dictates the effects of chronic nicotine exposure on different $\mathrm{nAChR}$ subtypes, and $\alpha 4 \beta 2$ nAChRs will be more severely affected than muscle-type nAChRs in human tobacco users. These observations also may have physiological significance, suggesting that persistent exposure to $\mathrm{ACh}$ at concentrations found in brain interstitial fluid (as high as $300 \mathrm{nmol} / \mathrm{L}$ in control subjects, based on microdialysis measurements and sensitive to effects of pharmacotherapeutic agents such as anticholinesterases) ${ }^{[33]}$ could modulate $\alpha 4 \beta 2-n A C h R$ function through persistent inactivation.

The extents of desensitization and rates of recovery from desensitization for human $\alpha 4 \beta 2$-nAChRs were determined in the current study using whole-cell current recording of peak current responses from a single cell as a function of the time of nicotine exposure during the desensitizing pulse. These values overlie the same measures made using isotopic ion flux assays integrating responses across the entire ensemble of nAChRs on hundreds of thousands of cells ${ }^{[2]}$. The same congruence of findings was observed for both ion flux-based ${ }^{[32]}$ and whole-cell recording-derived measures ${ }^{[1]}$ of the extent of desensitization and recovery from it for human muscle-type nAChRs. This clearly indicates that either technique can be used reliably to describe the recovery of $\mathrm{nAChRs}$ from agonist-induced desensitization and that ion flux measurements have as much experimental legitimacy in this regard as electrophysiological analyses. Ion flux assays are best suited for studies examining the effects of longerterm agonist pre-exposure on $\mathrm{nAChR}$ function and studies examining the slower phases functional recovery due to limitations in the time over which whole-cell current record- ings can be made from a given cell. Whole-cell recording is best suited for studies of shorter-term agonist pre-exposure because of its superior ability to resolve acute responses to agonists, and it permits the assessment of faster phases of $\mathrm{nAChR}$ functional recovery after shorter times of recovery. Experimental options are broadened by this demonstration of complementarity and congruence between ion flux and electrophysiological assessments.

There have been suggestions and some hard evidence that $\mathrm{nAChR}$ desensitization and recovery from it are related to post-translational modifications of the receptor. Considerable attention has turned to the $\mathrm{Ca}^{2+}$-dependent balance between dephosphorylation and phosphorylation in the modulation of those processes ${ }^{[24-26,34-38]}$. Whole-cell current and single channel recording can both be manipulated to assess $\mathrm{nAChR}$ desensitization under conditions where natural intracellular processes are preserved, as well as under conditions where those processes are manipulated to give insight into their nature. However, if there are post-translational changes, further work is needed to determine which changes correlate with specific stages of desensitization and how these changes relate to any discrete or continuous conformational changes in the receptor. Given the realization that both $\mathrm{nAChR}$ activation and inactivation may play prominent roles in the regulation of cholinergic function ${ }^{[5]}$, the current findings suggesting the existence of multiple desensitized states and the time and agonist dependencies for transitions between them are very pertinent to cholinergic function in health, disease, and nicotine dependence.

\section{Acknowledgements}

This project, part of which was conducted in the Charlotte and Harold Simensky Neurochemistry of Alzheimer's Disease Laboratory, was funded by the Arizona 
Disease Control Research Commission (9730 and 9615), the National Institutes of Health (NIH NS40417 and DA015389), the Roberta and Gloria Wallace Foundation, the Marjorie Newsome and Sandra Solheim Aiken fund, and the Men's and Women's Boards of the Barrow Neurological Foundation.

We thank J Brek EATON for cell maintenance and plating for electrophysiological studies and Dr Raphael GRUENER and Marsha SEGERBERG for critical readings of the manuscript.

\section{Author contribution}

Dr Ronald J LUKAS and Dr Jie WU designed the research, analyzed the data, and wrote the article; Dr Kewei D YU and Dr Qiang LIU performed patch clamp experiments, analyzed the data, and wrote the article.

\section{References}

1 Reitstetter R, Lukas RJ, Gruener R. Dependence of nicotinic acetylcholine receptor recovery from desensitization on the duration of agonist exposure. J Pharmacol Exp Ther 1999; 289: 656-60.

2 Gentry CL, Wilkins LH, Lukas RJ. Effects of prolonged nicotinic ligand exposure on function of heterologously expressed, human $\alpha 4 \beta 2$ - and $\alpha 4 \beta 4$-nicotinic acetylcholine receptors. J Pharmacol Exp Ther 2003; 304: 206-16.

3 Lukas RJ, Changeux JP, le Novere N, Albuquerque EX, Balfour $\mathrm{DJK}$, Berg DK, et al. International Union of Pharmacology. XX. Current status of the nomenclature for nicotinic acetylcholine receptors and their subunits. Pharmacol Rev 1999; 51: 397-401.

4 Flores CM, Rogers SW, Pabreza LA, Wolfe BB, Kellar KJ. A subtype of nicotinic cholinergic receptor in rat brain is composed of alpha 4 and beta 2 subunits and is up-regulated by chronic nicotine treatment. Mol Pharmacol 1992; 41: 31-7.

5 Gentry CL, Lukas RJ. Regulation of nicotinic acetylcholine receptor numbers and function by chronic nicotine exposure. Curr Drug Targets CNS Neurol Disord 2002; 1: 359-85.

6 Schwartz RD, Kellar KJ. Nicotinic cholinergic receptor binding sites in the brain: regulation in vivo. Science 1983; 220: 214-6.

7 Marks MJ, Stitzel JA, Collins AC. Time course study of the effects of chronic nicotine infusion on drug response and brain receptors. J Pharmacol Exp Ther 1985; 235: 619-28.

8 Benwell MEM, Balfour DJK, Anderson JM. Evidence that tobacco smoking increases the density of (-)-[ $\left.{ }^{3} \mathrm{H}\right]$ nicotine binding sites in human brain. J Neurochem 1988; 50: 1243-7.

9 Whitehouse PJ, Martino AM, Marcus KA, Zweig RM, Singer HS, Price DL, et al. Reductions in acetylcholine and nicotine binding in several degenerative diseases. Arch Neurol 1988; 45: 722-4.

10 Lange KW, Wells FR, Jenner P, Marsden CD. Altered muscarinic and nicotinic receptor densities in cortical and subcortical brain regions in Parkinson's disease. J Neurochem 1993; 60: 197-203.

11 Baron JA. The epidemiology of cigarette smoking and Parkinson's disease. Neurology 1986; 36:1490-6.
12 Steinlein OK, Mulley JC, Propping P, Wallace RH, Phillips HA, Sutherland GR, et al. A missense mutation in the neuronal nicotinic acetylcholine receptor alpha 4 subunit is associated with autosomal dominant nocturnal frontal lobe epilepsy. Nat Genet 1995; 11: 201-3.

13 Silver AA, Shytle RD, Philipp MK, Wilkinson BJ, McConville B, Sanberg PR. Transdermal nicotine and haloperidol in Tourette's disorder: a double-blind placebo-controlled study. J Clin Psychiatry 2001; 62: 707-14.

14 Lauder JM, Schambra UB. Morphogenetic roles of acetylcholine. Environmen Health Persp 1999; 107 Suppl 1: 65-9.

15 Jones S, Sudweeks S, Yakel JL. Nicotinic receptors in the brain: correlating physiology with function. Trends Neurosci 1999; 22: 555-61.

16 Katz B, Thesleff S. A study of the desensitization produced by acetylcholine at the motor end-plate. J Physiol 1957; 138: 63-80.

17 Sakmann B, Patlak J, Neher E. Single acetylcholine-activated channels show burst-kinetics in presence of desensitizing concentrations of agonist. Nature 1980; 286: 71-3.

18 Feltz A, Trautmann A. Desensitization at the frog neuromuscular junction: a biphasic process. J Physiol 1982; 322: 257-72.

19 Boyd ND. Two distinct kinetic phases of desensitization of acetylcholine receptors of clonal rat PC12 cells. J Physiol 1987; 389: 45-67.

20 Eaton JB, Peng JH, Schroeder KM, George AA, Fryer JD, Krishnan $\mathrm{C}$, et al. Characterization of human $\alpha 4 \beta 2$-nicotinic acetylcholine receptors stably and heterologously expressed in native nicotinic receptor-null sh-ep1 human epithelial cells. Mol Pharmacol 2003; 64: 1283-94.

21 Wu J, Zeng YX, Hirokawa K. Signal pathway of mitogen-induced $\mathrm{Ca}^{2+}$-activated $\mathrm{K}^{+}$currents in young and aged $\mathrm{T}$-cell clones of C57BL/6 mice. Cell Signal 1999; 11:391-8.

22 Bufler J, Franke C, Parnas H, Dudel J. Open channel block by physostigmine and procaine in embryonic-like nicotinic receptors of mouse muscle. Eur J Neurosci 1996; 8: 677-87.

23 Spitzmaul G, Dilger JP, Bouzat C. The noncompetitive inhibitor quinacrine modifies the desensitization kinetics of muscle acetylcholine receptors. Mol Pharmacol 2001; 60: 235-43.

24 Cachelin $\mathrm{AB}$, Colquhoun D. Desensitization of the acetylcholine receptor of frog end-plates measured in a vaseline-gap voltage clamp. J Physiol 1989; 415: 159-88.

25 Khiroug L, Sokolova E, Giniatullin R, Afzalov R, Nistri A. Recovery from desensitization of neuronal nicotinic acetylcholine receptors of rat chromaffin cells is modulated by intracellular calcium through distinct second messengers. J Neurosci 1998; 18: 2458-66.

26 Paradiso K, Brehm P. Long-term desensitization of nicotinic acetylcholine receptors is regulated via protein kinase A-mediated phosphorylation. J Neurosci 1998; 18: 9227-37.

27 Krampfl K, Jahn K, Cordes AL, Dengler R, Bufler J. Analysis of a slow desensitized state of recombinant adult-type nicotinic acetylcholine receptor channels. Eur J Neurosci 2002; 16: 652-8.

28 Lukas RJ. Effects of chronic nicotinic ligand exposure on functional activity of nicotinic acetylcholine receptors expressed by cells of the PC12 rat pheochromocytoma or the TE671/RD human clonal line. J Neurochem 1991; 56: 1134-45.

29 Peng X, Gerzanich V, Anand R, Whiting PJ, Lindstrom J. Nicotine-induced increase in neuronal nicotinic receptors results from a 
decrease in the rate of receptor turnover. Mol Pharmacol 1994; 46: 523-30.

30 Khakh BS, Bao XR, Labarca C, Lester HA. Neuronal P2X transmitter-gated cation channels change their ion selectivity in seconds. Nat Neurosci 1999; 2: 322-30.

31 Virginio C, MacKenzie A, Rassendren FA, North RA, Surprenant A. Pore dilation of neuronal P2X receptor channels. Nat Neurosci 1999; 2: 315-21.

32 Ke L, Eisenhour CM, Bencherif M, Lukas RJ. Effects of chronic nicotine treatment on expression of diverse nicotinic acetylcholine receptor subtypes. I. Dose-and time-dependent effects of nicotine treatment. J Pharmacol Exp Ther 1998; 286: 825-40.

33 Quinn DM, Balasubramanian AS, Doctor BP, Taylor P. Enzymes of the cholinesterase family. New York: Plenum Press; 1995.

34 Middleton P, Rubin LL, Schuetze SM. Desensitization of acetylcholine receptors in rat myotubes is enhanced by agents that elevate intracellular cAMP. J Neurosci 1988; 8: 3405-12.

35 Hoffman PW, Ravindran A, Huganir RL. Role of phosphorylation in desensitization of acetylcholine receptors expressed in Xenopus oocytes. J Neurosci 1994; 14: 4185-95.

36 Eilers H, Schaeffer E, Bickler PE, Forsayeth JR. Functional deactivation of the major neuronal nicotinic receptor caused by nicotine and a protein kinase C-dependent mechanism. Mol Pharmacol 1997; 52: 1105-12.

37 Fenster CP, Rains MF, Noerager B, Quick MW, Lester RA. Influence of subunit composition on desensitization of neuronal acetylcholine receptors at low concentrations of nicotine. J Neurosci 1997; 17: 5747-59.

38 Fenster CP, Beckman ML, Parker JC, Sheffield EB, Whitworth TL, Quick MW, et al. Regulation of $\alpha 4 \beta 2$ nicotinic receptor desensitization by calcium and protein kinase C. Mol Pharmacol 1999; 55: 432-43. 